\title{
COMPARATIVE ANALYSIS OF THE INFLUENCE OF CHLORINE AND FLUORINE ANIONS ON THE FIBRIN POLYMERIZATION
}

\author{
L. V. PYROGOVA ${ }^{1}$, G. K. BEREZNITSKY', G. K. GOGOLINSKAYA ${ }^{1}$, T. M. PLATONOVA ${ }^{1}$, \\ I. M. KOLESNIKOVA, O. O. MASENKO ${ }^{1}$, R. Yu. MARUNICH ${ }^{1}$, P. Yu. TSAP ${ }^{1}$, \\ Yu. V. USHENIN ${ }^{2}$, Y. M. MAKOGONENKO ${ }^{1 凶}$, E. V. LUGOVSKOI \\ ${ }^{1}$ Palladin Institute of Biochemistry, National Academy of Sciences of Ukraine, Kyiv; \\ ${ }^{2}$ V.E. Lashkaryov Institute of Semiconductor Physics, \\ National Academy of Sciences of Ukraine, Kyiv; \\ e-mail: ymakogonenko@gmail.com
}

Received: 25 April 2019; Accepted: 18 October 2019

The effect of $\mathrm{NaCl}$ and $\mathrm{NaF}$ salts in the range of 0.1-0.225 $\mathrm{M}$ concentrations on individual stages of fibrin polymerization was investigated, namely: the rate of fibrinogen activation by thrombin, the rate of protofibrils formation, the rate of lateral association of protofibrils, and the maximum clot absorbance value at $350 \mathrm{~nm}$. It was found that the chlorine and fluorine anions equally inhibit the rate of formation of fibrin from fibrinogen and the formation of protofibrils activated with thrombin. Chlorine anions were shown to be significantly more effective than fluorine anions, inhibiting the rate of lateral association and maximal clot absorbance level from fibrin desA and desAB. A component of the inhibitory action of chlorine anions, not related to the ionic strength of the solution, was identified and its effect on the individual polymerization steps was shown. Chlorine anions were found to bind to a fibrin clot. Using the surface plasmon resonance method and fibrin-specific $\mathrm{mAb} F \mathrm{FI}-3 \mathrm{c}$, it was established that the rate of exposure of neoantigenic determinants of $m A b$ in the hinge regions of the fibrinogen molecule during its transformation into fibrin under the action of thrombin is inhibited by chlorine anions in correlation with inhibition of the protofibril lateral association rate. It has been suggested that the inhibitory effect of chlorine anions consists of an ionic component and a component that blocks the conformational mobility of the molecule by the chlorine anions binding to its hinge regions and polymerization sites.

Ke y wo rds: fibrinogen, fibrin, polymerization, chlorine and fluorine anions.

$\mathrm{F}$ ibrinogen is one of the major proteins in the human hemostasis system. Under the action of thrombin, it is transformed into fibrin, which spontaneously polymerizes with the formation of a polymer insoluble mesh - the basis of the thrombus, which ensures the integrity of blood vessels and the body as a whole, and further functions as a matrix for the processes of regeneration of damaged blood vessels and tissues of the body $[1,2]$. The process of fibrinogen polymerization is extremely complex and multi-stage. In the first stage, thrombin cleaves two $\mathrm{N}$-terminal fibrinopeptides A from the $\alpha$-chains of fibrinogen to form an interme- diate form of fibrin - fibrin desA. Transformation of fibrinogen into fibrin desA causes structural changes in the molecule, increased mobility of individual domains, and exposure of polymerization sites A [35]. Due to the appearance of the latter sites, fibrin desA is spontaneously polymerized by the face-toface interaction of the molecules with half-molecule shifting and the formation of double-stranded oligomers - protofibrils. Upon reaching protofibrils of length $\sim 16$ monomers, they associate laterally with the formation of fibrils. At the same time, two fibrinopeptides B are cleaved from the $\beta$-chains of the molecule and exposed the $\mathrm{B}$ polymerization

(C) 2019 Pyrogova L. V. et al. This is an open-access article distributed under the terms of the Creative Commons Attribution License, which permits unrestricted use, distribution, and reproduction in any medium, provided the original author and source are credited. 
sites, which increase the rate of polymerization, the branching of the fibrils and the formation of the fibrin clot network [6].

The rate of the fibrin clot formation and its structure depend on many factors of the reaction medium, primarily the $\mathrm{pH}$, ionic composition and ion concentration [7-9]. It was found that anions of the halogen group, with the exception of the fluorine anion, strongly inhibit the polymerization of fibrin. Thus, chlorine anions specifically inhibited the rate of lateral association of protofibrils, reduced the thickness of the fibrin fibers by about an order of magnitude, and changed the structure of the clot [10]. The authors suggested that the inhibition of the lateral association of protofibrils by the chlorine anions was caused not only by the effect of ionic strength but also by the stabilization of the intermediate forms of the polymerizing fibrin molecules. Our task was to investigate the influence of chlorine ions at all stages of the polymerization process of desA and desAB forms of fibrin, namely: the rate of fibrin formation and transformation of fibrinogen into fibrin, the rate of formation of protofibrils and their lateral association, the final turbidity of the fibrin clot. Fluoride anions were chosen as the comparison anions, which, as shown [10], did not affect the polymerization of fibrin.

\section{Materials and Methods}

The next reagents $\mathrm{NaCl}, \mathrm{NaF}, \mathrm{Na}_{2} \mathrm{HPO}_{4}$, $\mathrm{NaH}_{2} \mathrm{PO}_{4}, \mathrm{NaOH}, \mathrm{HCl}, \mathrm{CaCl}_{2}$, tris (three hydroxymethylaminomethan), HEPES (2-[4-(2-hydroxy) piperazine-1-il)ethanesulphonic acid, tween 20, water-soluble carbodiimide, N-hydroxysuccinimide, Gly-Pro-Arg-Pro peptide, heparin, thrombin, aprotinin were purchased from Sigma. Fibrinogen was isolated from donor plasma by salting with $\mathrm{Na}_{2} \mathrm{SO}_{4}$ [11]. Fibrin desAB was prepared by fibrin clot dissolution in acetic acid [12]. Fibrin- and fibrinogen-specific monoclonal antibodies FnI-3c and II-4d, respectively, were prepared at the department of molecular immunology of Palladin Institute of Biochemistry of NAS of Ukraine [13, 14]. Antithrombin III was isolated from the donor plasma by affinity chromatography on heparin- Sepharose [15]. Reptilase-like enzyme Ancistron $\mathrm{H}$ was isolated from venom of snake Agkistrodon halys halys [16].

The effect of $\mathrm{NaCl}$ and $\mathrm{NaF}$ on fibrin polymerization was determined by spectrophotometric method by recording of light absorbance by fibrin clot at $350 \mathrm{~nm}$ with spectrophotometer SF-2000 [13].
The clot was formed in spectrophotometric cell, in which were consistently added a 0.02 M HEPES buffer, $\mathrm{pH} 7.4$, containing $\mathrm{NaCl}$ or $\mathrm{NaF}$ at indicated concentration, and fibrinogen to a final concentration from 100 to $300 \mu \mathrm{g} / \mathrm{ml}$. The process of polymerization was initiated by the addition of thrombin or ancistron $\mathrm{H}$ to the indicated concentrations. The final volume of the reaction mixture was $400 \mu$ l.

The curve of turbidity growth during the fibrin polymerization had the following parameters: $\tau, \mathrm{s}-$ lag period, $\mathrm{s}$ - represents the time of protofibrils formation in seconds, the rate of protofibrils formation was determined as $V=1 / \tau, \mathrm{s}^{-1} ; V_{\max }$, o.u./s - maximal velocity of turbidity growth, defined as tg of the largest inclination angle of the fibrin turbidity growth curve at $350 \mathrm{~nm}$ to the abscissa, $V_{\max }$ represents the rate of the lateral association of protofibrils; $\mathrm{H}$, o.u. - maximum turbidity of the fibrin clot at $350 \mathrm{~nm}$, which reflects the thickness of the fibrils in the clot [17].

Exposure of neoantigenic determinant on fibrinogen molecule after cleavage of fibrinopeptides A under the action of thrombin or ancistron $\mathrm{H}$ was registered in real time using the plasmon resonance method and a plasmon spectropolarimeter device developed and manufactured at VE Lashkaryov Institute of Semiconductors of NAS of Ukraine, and an immunosensory chip with a covalently immobilized fibrin-specific monoclonal antibody FnI-3c.

The FnI-3c monoclonal antibody was covalently immobilized on the immunosensor chip using standard chemistry of protein binding via amino group with a pre-functionalized gold plate surface containing carboxyl groups.

To investigate the effect of $\mathrm{NaCl}$ or $\mathrm{NaF}$ on the in situ interaction between fibrin and $\mathrm{mAb}$ FnI-3c, fibrinogen was passed into control cell at a concentration of 3-5 $\mu \mathrm{g} / \mathrm{ml}$ in 0.02 M HEPES buffer, $\mathrm{pH} 7.4$, a given salt concentration, $0.005 \%$ tween 20 , and $1 \mathrm{mM}$ concentration of GPRP peptide that blocked polymerization and supported fibrin molecules in monomeric form. Fibrinogen was placed in the measuring cell in the same medium at $0.05 \mathrm{NIH} / \mathrm{ml}$ thrombin or ancistrone concentration, which initiated the fibrinogen polymerization. In the figures, each curve represents the difference in the values of the signals between the measuring and control cells. The increase in the magnitude of the differential signal indicated the appearance of neoantigenic determinants on the fibrinogen molecule during its transformation into fibrin after cleavage of fibrinopeptides A. 
The amount of chlorine anions bound to the fibrin in the clot was determined using a mercurimetric method of titration a solution containing chlorine anions with a solution of divalent mercury nitric acid [18]. The titer of nitric acid mercury was set using $0.1 \mathrm{M}$ sodium chloride solution and was $0.467 \mathrm{~N}$. $2 \%$ solution of diphenylcarbazone was used as an indicator. The titration was performed using a microtiter, the price of dividing of which was $0.166 \mu 1$. The clot was formed in 0.02 M HEPES buffer, $\mathrm{pH} 7.4$, which contained $0.15 \mathrm{M} \mathrm{NaCl}, 1 \mathrm{mg} / \mathrm{ml}$ fibrinogen, by adding thrombin to a concentration of $0.1 \mathrm{NIH} /$ $\mathrm{ml}$ and incubated at room temperature for $30 \mathrm{~min}$. The fibrin clot was wound on a glass rod, completely removed with water on filter paper and transferred to a $5 \mathrm{ml}$ titration cup; $1 \mathrm{ml}$ of water, $20 \mu \mathrm{l}$ of diphenylcarbazone, $50 \mu \mathrm{l}$ of $0.1 \mathrm{~N}$ nitric acid were added and titrated with a solution of $0.004 \mathrm{~N}$ nitric acid mercury. Chlorine anions concentration was determined from a calibration curve constructed using a standardized $\mathrm{NaCl}$ solution.

Statistical processing of the results was performed using a standard statistical program in Excel. The mean values of the parameters and their standard deviation were determined.

\section{Results and Discussion}

The influence of increasing concentrations of $\mathrm{NaCl}$ and $\mathrm{NaF}$ on the polymerization of fibrinogen activated by thrombin or ancistron. The effect of increasing concentration of chlorine and fluo-

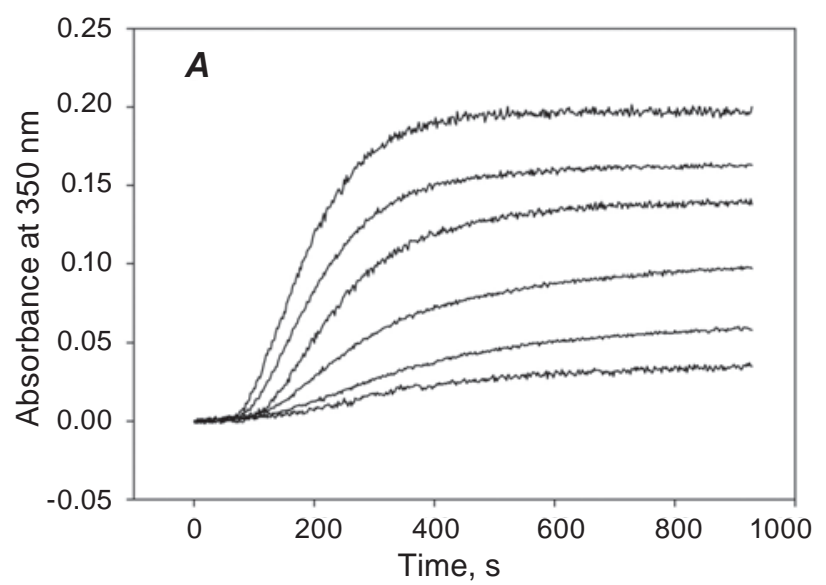

rine anions on the rate of individual stages of fibrin polymerization (the rate of protofibril formation, the rate of their lateral association, and the final clot turbidity) was investigated in systems with fibrin desA (Fg + ancistron) and fibrin desAB (Fg + thrombin).

Using the turbidimetry method, it was found that $\mathrm{NaCl}$ inhibits all stages of fibrin desA and desAB polymerization more significantly than $\mathrm{NaF}$ (Fig. 1, Fig. 2). Thus, in a system with fibrin desA, increasing the concentration of $\mathrm{NaCl}$ from $0.1 \mathrm{M}$ to $0.225 \mathrm{M}$ reduced the rate of protofibril formation by 2.3 times, the rate of lateral association of protofibrils by 14.3 times, and the final clot turbidity by 5.6 times (Fig. 1, A).

At the same time, $\mathrm{NaF}$ did not affect any stage of polymerization of fibrin desA (Fig. 1, B). $\mathrm{NaCl}$ at $0.1 \mathrm{M}$ concentration more strongly inhibited all stages of polymerization of fibrin desA compared to $0.1 \mathrm{M} \mathrm{NaF}$ by 2.6, 4.1 and 2.4 times, respectively. Increasing the concentration of $\mathrm{NaCl}$ from $0.1 \mathrm{M}$ to $0.225 \mathrm{M}$, Fig. 2, A, also inhibited all stages of polymerization of fibrin desAB: the rate of formation of protofibrils - 6.1 times, the rate of lateral association of protofibrils - 12.7 times, the final turbidity of the clot - 9,8 times. NaF inhibited these polymerization steps by 1.13, 1.09 and 1.06 times, respectively (Fig. 2, B). Fig. 3 shows the normalized (in percent relative to the initial values at $0.1 \mathrm{M}$ salt concentration) graphs of the rate of protofibrils formation, their lateral association and the magnitude of the clot turbidity from increasing salt concentrations.

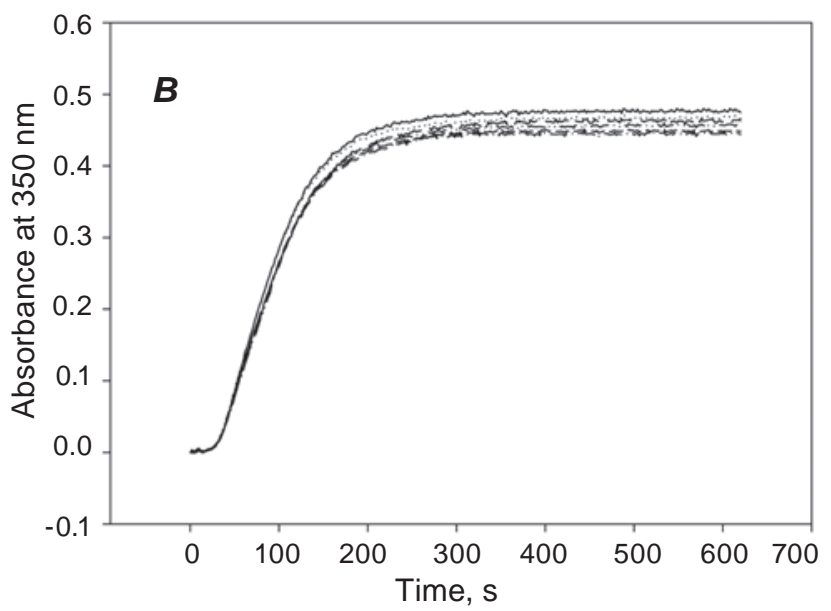

Fig. 1. The effect of increasing concentrations of $\mathrm{NaCl}(\mathbf{A})$ and $\mathrm{NaF}(\boldsymbol{B})$ on the polymerization of fibrin formed in the system of fibrinogen $(150 \mu \mathrm{g} / \mathrm{ml})$ and ancistron $\mathrm{H}(0.25 \mathrm{NIH} / \mathrm{ml})$. The reaction was carried out in $0.02 \mathrm{M}$ HEPES buffer, pH 7.4, a given salt concentration, 0.005\% tween 20. The concentrations of salts for the curves from top to bottom are: 0.1, 0.125, 0.15, 0.175, 0.2 and 0.225 M. Each curve is an averaged curve of three independent experiments 

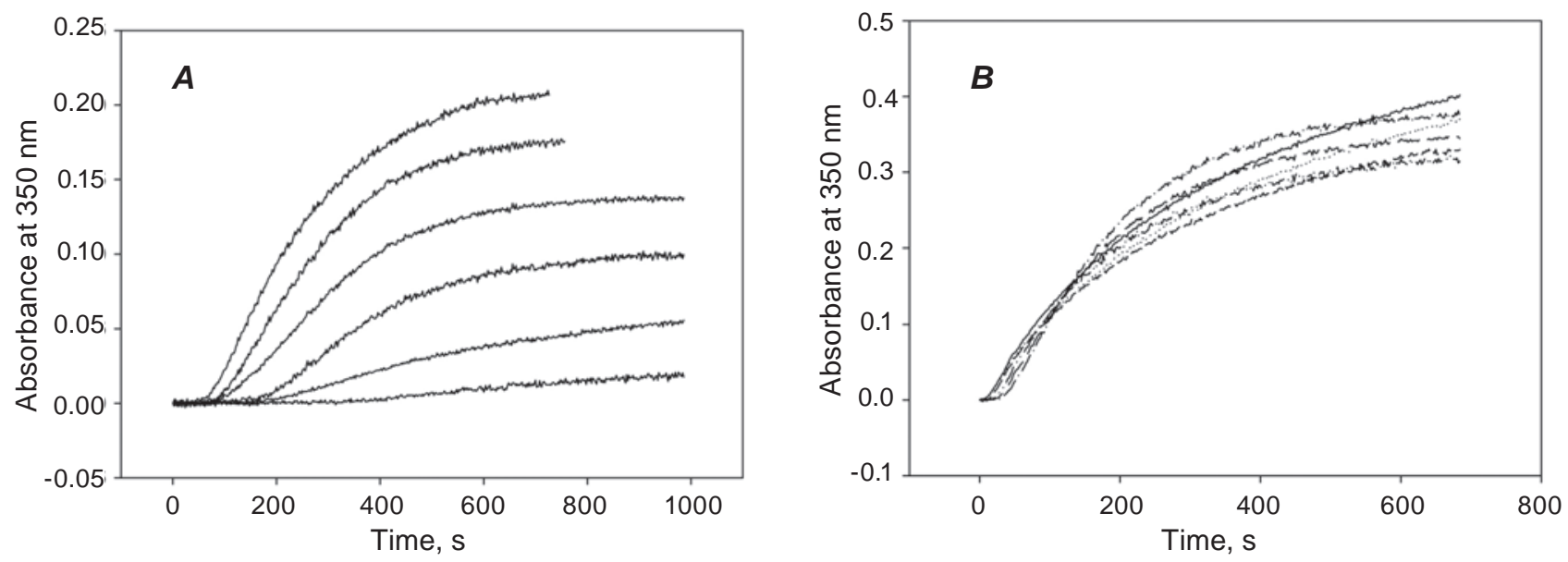

Fig. 2. The effect of increasing concentrations of $\mathrm{NaCl}(\mathbf{A})$ and $\mathrm{NaF}(\mathbf{B})$ on the polymerization of fibrin formed in the system of fibrinogen $(150 \mu \mathrm{g} / \mathrm{ml})$ and thrombin $(0.25$ units $N I H / \mathrm{ml})$. Salt concentrations on curves (A) are shown from top to bottom, and curves (B) from bottom to top are: 0.1, 0.125, 0.15, 0.175, 0.2, and 0.225 M. Each curve is averaged curve of three independent experiments

Comparison of the influence of chlorine and fluorine anions on the magnitude of the parameters of the individual stages of polymerization of fibrin desA and desAB indicates that chlorine anions significantly inhibit all the stages of polymerization of both fibrin forms with the exception of the protofibrils formation stage of fibrin desAB (Fig. 3, B). The inhibitory influence of ionic strength of chlorine and fluorine anions is based on the electrostatic interaction of anions with water molecules and fibrin (fibrinogen) molecules in solution [19]. Because fluorine anions have a hydrated shell of 5 water molecules, their interaction with protein molecules and ions is weakened [20]. Chlorine anions have a very small hydrate shell of 2 water molecules, a larger atomic radius of $1.81 \AA$, which facilitates their interaction with functional groups of proteins [21]. Anions of chlorine and fluorine with greater efficiency inhibit the formation of protofibrils of fibrin desAB compared with fibrin desA, at the same time the degree of inhibition by both anions of the rate of fibrin desAB protofibrils formation is the same (Fig. 3, B). Chlorine anions inhibit the rate of lateral association of protofibrils of both fibrin forms with the highest efficiency. At the same time, fluorine anions do not affect the rate of lateral association of the protofibrils of fibrin desA, however, they increase by $\sim 44 \%$ the same for fibrin desAB. Chlorine anions significantly reduce the clot turbidity (fibril diameter [17]) of both fibrin forms (Fig. 3, C), and disrupt the fibrillar clot structure unlike fluorine anions, which do not affect the clot turbidity (fibrillar structure) [9].
The inhibitory effect of chlorine anions on the fibrin polymerization besides the ionic strength includes an additional component that can be considred as a specific inhibitory effect associated with their ability to bind to the protein and stabilize its structure [10]. The difference between the effects of chlorine and fluorine anions can be considered as the value of the specific inhibitory effect of chlorine anions, which is presented for all stages of the process of polymerization of fibrin desA and desAB in Fig. 4. The curves in Fig. 4, $A$ and the curve of the lateral association of protofibrils inhibition in Fig. 4, $B$ are saturation curves indicating the binding of chlorine anions to fibrin molecules. The data obtained indicate that the increase in the concentration of chlorine anions is accompanied by strong specific inhibition of the rate of lateral association of protofibrils of both fibrin forms, the final turbidity of clot fibrin desA and a slightly lower inhibition of the stage of protofibril formation of fibrin desAB. The effect of chlorine anions is more pronounced on desAB fibrin than desA fibrin. It can be assumed that these differences are related to different polymerization sites involved in the polymerization process in both fibrin forms. So, in desA fibrin, there are six pairs of sites, namely: "A" - "a", B $\beta N$ domain ("C") - "c", $\gamma 350-360, \gamma 370-380, \gamma 275-300$, and peptides related to hinge regions of the molecule - A $\alpha 99-110$, B $\beta 130$ 150 and $\gamma 70-100[19,22,23]$. The leading forces of inter-sites interactions in desA fibrin are the electrostatic forces of ionic and hydrogen bonds $[6,19]$. In the des $\mathrm{AB}$ fibrin to the named sites are additionally 
Fibrin desA
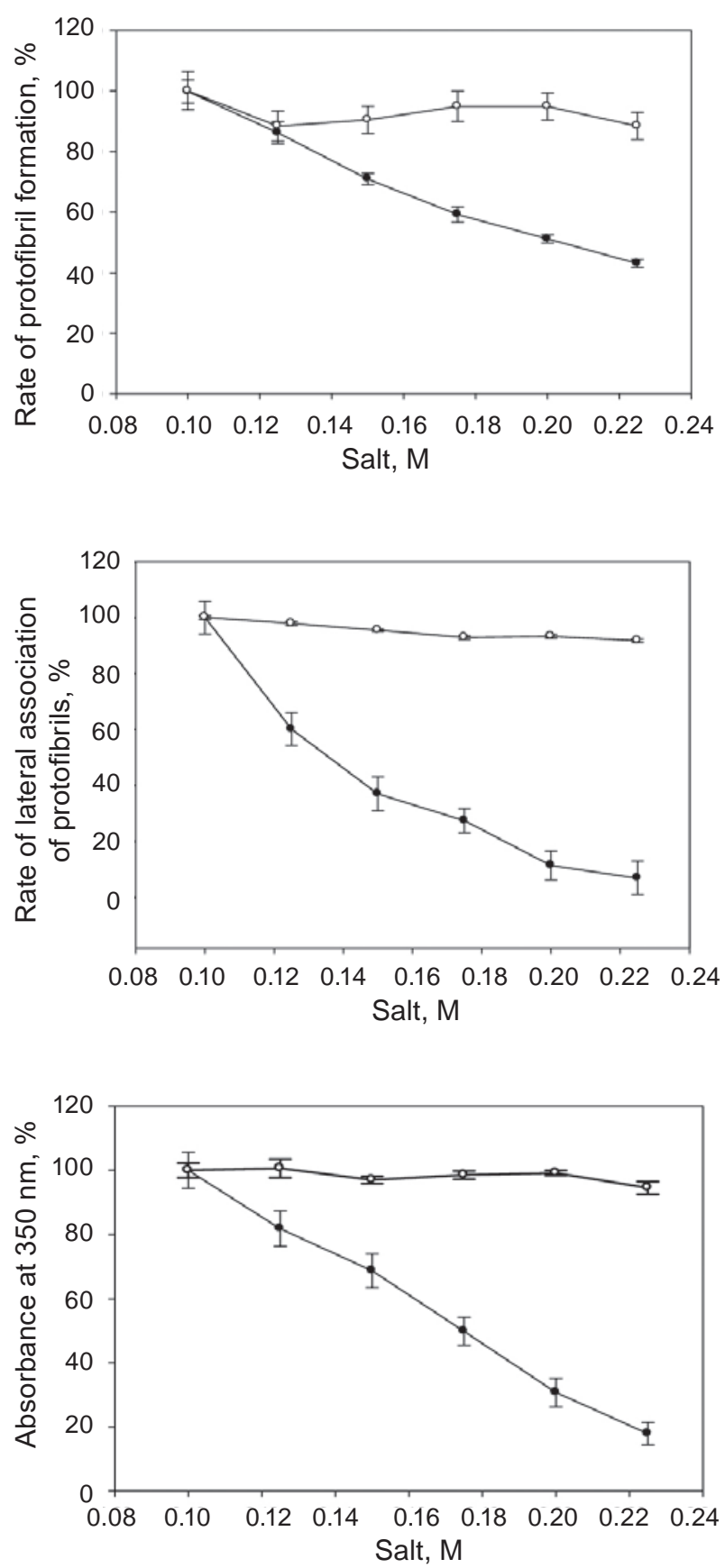

Fibrin desAB

A

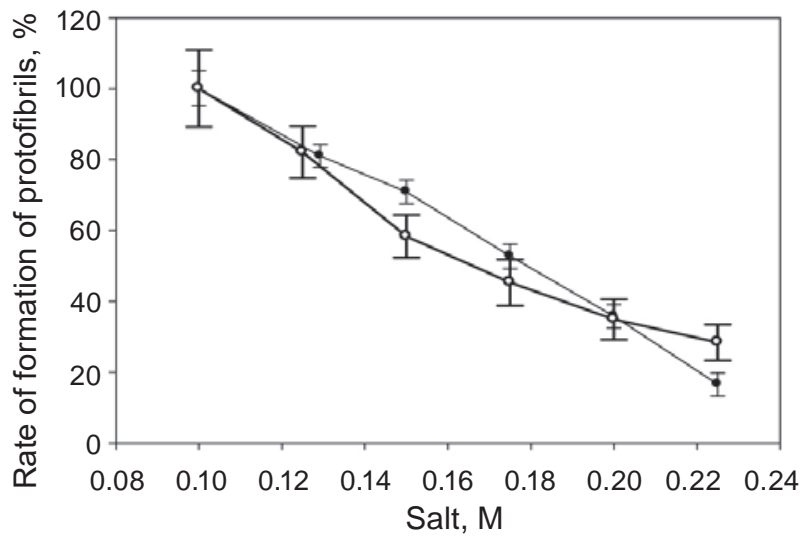

B

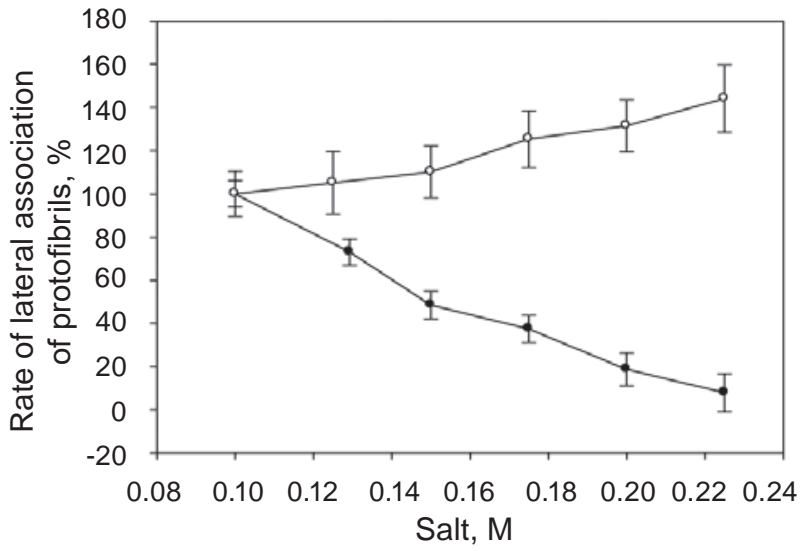

C

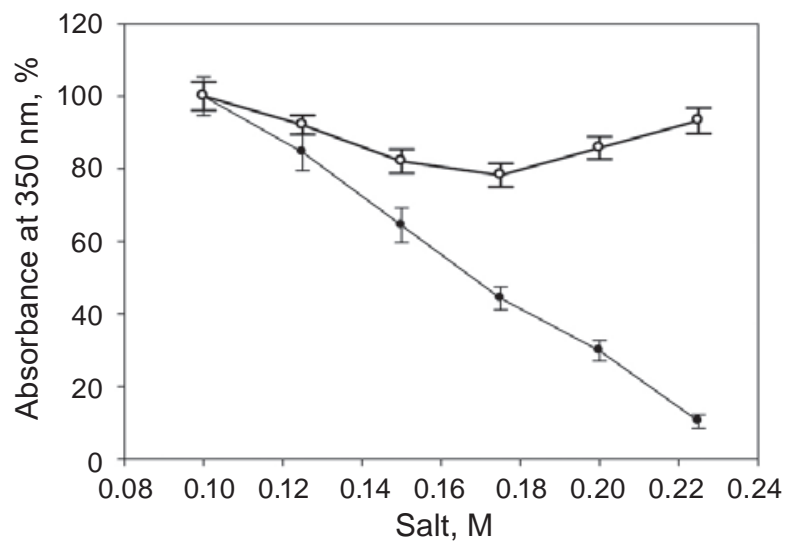

Fig. 3. Normalized curves of the dependence of the rate of formation of protofibrils (A), lateral association of protofibrils (B) and maximum clot turbidity (C) for fibrinogen activated by ancistron $H$ (fibrin desA) or thrombin (fibrin desAB) on the concentration of $\mathrm{NaCl}$ or $\mathrm{NaF}$. The response value equal of $100 \%$ was taken at $0.1 \mathrm{M}$ salt concentration. The NaF curves are indicated by light labels and $\mathrm{NaCl}$ by dark labels

joined the sites, involved in the lateral association of protofibrils - "B" and "b", B $\beta 330-375$ and $\alpha \mathrm{C}$ regions of the molecule $[3,19,23]$. These sites interact mainly at the stage of the lateral association of protofibrils due to hydrogen and hydrophobic interactions, which increases the affinity of the interaction of protofibrils fibrin desAB with each other and reduces the inhibitory effect of chlorine anions. This leads to a 

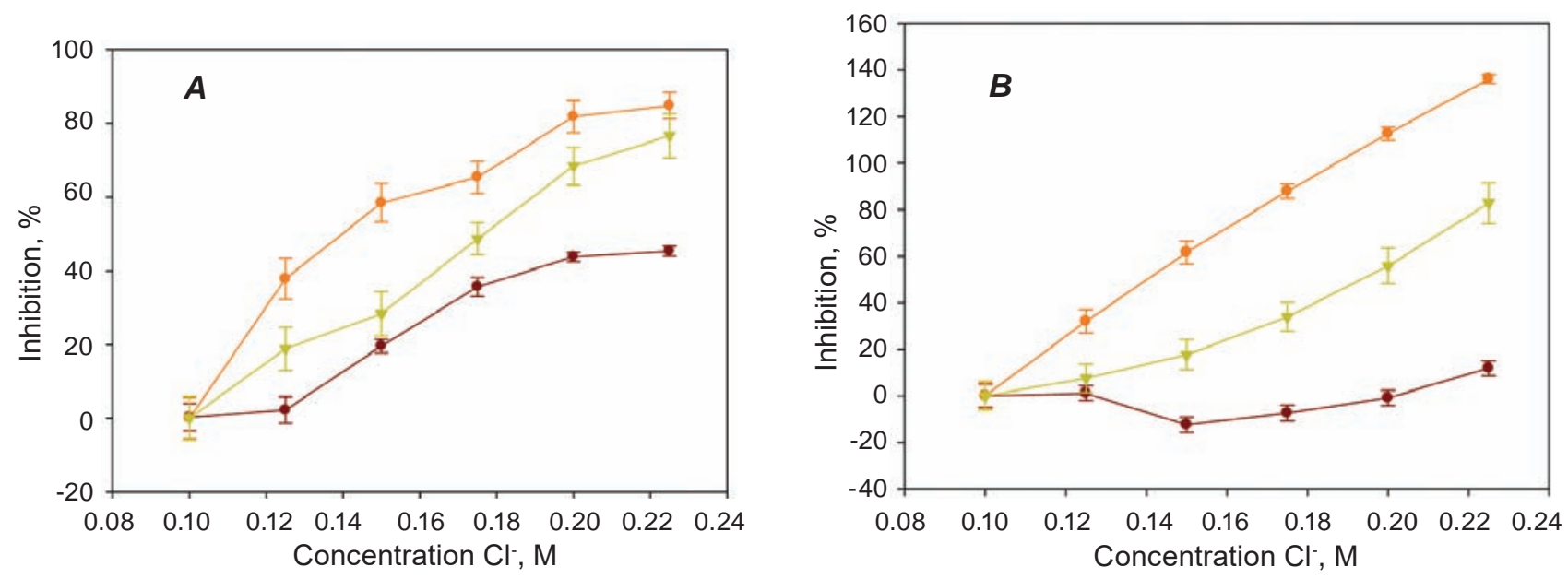

Fig. 4. The dependence of the level of specific inhibition by chlorine anions of the individual stages of polymerization of fibrin desA (A) and desAB (B), which are presented as the difference between the values of inhibition of the stages of polymerization of fibrin with $\mathrm{NaF}$ and $\mathrm{NaCl}$ salts. Beet color indicates the curves of inhibition of the rate of formation of protofibrils, orange - the rate of the lateral association of protofibrils, light green - curves of inhibition of the maximum turbidity of the clots

decrease in clot turbidity by reducing the thickness of the fibrils (formally increasing the inhibition) and increasing their number (forming thin gels) [10].

It is important to note that fluorine ions differently inhibit the polymerization of desA and desAB forms of fibrin. They have almost no effect on the stage of polymerization of fibrin desA, Fig. 3, and show the opposite directed action at the stage of fibrin desAB protofibrils formation and their lateral association (Fig. 4, B). Taking into account that the hydration shell of fluorine ions has 5 water molecules, at an anion concentration of $0.225 \mathrm{M}$, the concentration of hydration water in the solution will be $1.125 \mathrm{M}$, and, given the hydration water of the Na cations, about $2.25 \mathrm{M}$ of all water in the solution. Since the formation of the desAB form of fibrin is also accompanied by significant binding of water to its molecule (about $0.1 \mathrm{~g}$ of $\mathrm{H}_{2} \mathrm{O}$ per $1 \mathrm{~g}$ of protein [24]), or 1800 water molecules per 1 molecule of fibrin, it can be assumed that the change of water structure under the action of anions fluoride and increasing the hydrate layer of the fibrin molecule desAB may lead, on the one hand, to a greater inhibition of the rate of formation of protofibrils, and, on the other, to an increase in the clot turbidity during the polymerization of desAB form of fibrin.

Thus, we assume that inhibition of fibrin polymerization by chlorine anions is due to the effect of ionic strength and the specific inhibitory effect caused by the binding of chlorine ions to the fibrin molecule, primarily at the loci that enter the polyme- rization sites of the molecule. Fluorine anions affect the fibrin polymerization, apparently also by influencing the structure of water in the reaction medium.

Comparative analysis of the rate of fibrin formation from thrombin-activated fibrinogen in the presence of $\mathrm{NaCl}$ or $\mathrm{NaF}$. It is established that the enzyme activity and specificity of thrombin are regulated by $\mathrm{Na}$ ions. Because chlorine and fluorine anions have different effects on fibrin polymerization, it was important to find out their effect on the enzymatic stage of fibrin polymerization, namely their effect on the rate of fibrin formation reaction.

For this purpose, a clot was formed in $0.02 \mathrm{M}$ HEPES buffer, $\mathrm{pH} 7.4$, containing $0.15 \mathrm{M} \mathrm{NaCl}$ or $\mathrm{NaF}, 0.3 \mathrm{mg} / \mathrm{ml}$ fibrin or fibrinogen activated with $0.1 \mathrm{NIH} / \mathrm{ml}$ thrombin, and $2 \mathrm{mM}$ iodine acetic acid as an inhibitor of factor XIIIa (Fig. 5). Comparison of the effect of chlorine and fluorine anions on the polymerization of monomeric fibrin desAB and thrombin activated fibrinogen indicates a more pronounced effect on fibrin polymerization than that of thrombin activated fibrinogen (Fig. 5). This can be explained by the fact that the preparation of the soluble fibrin desAB is in acetic acid, $\mathrm{pH}$ 4.1, and the structure of the fibrin molecule is partially denatured [8]. Transfer of fibrin to HEPES buffer, $\mathrm{pH} 7.4$, induces refolding of disordered fibrin domains first of all $\alpha \mathrm{C}$-regions and $\mathrm{B} \beta \mathrm{N}$-domains. This is supported by the lengthening of the lag-period of the fibrin polymerization reaction, compared to that in the fibrinogen + thrombin system. In this case, chlorine 
A

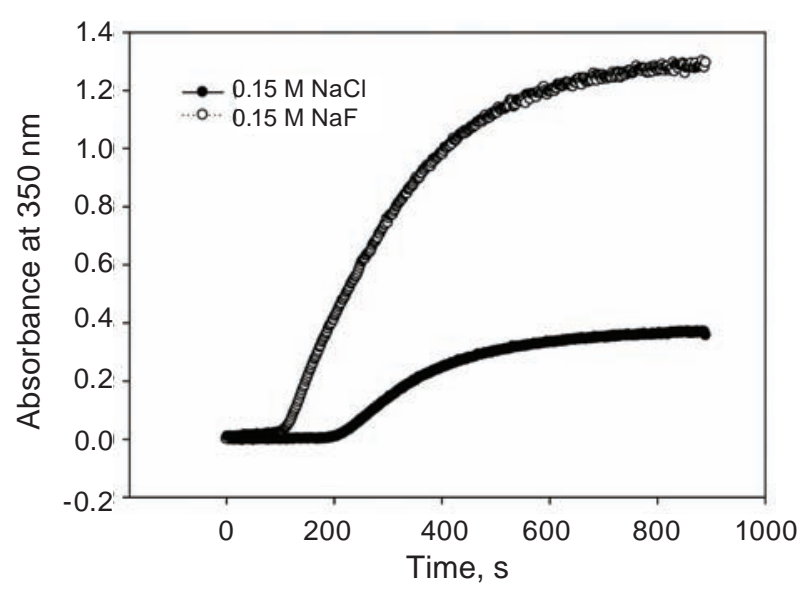

B

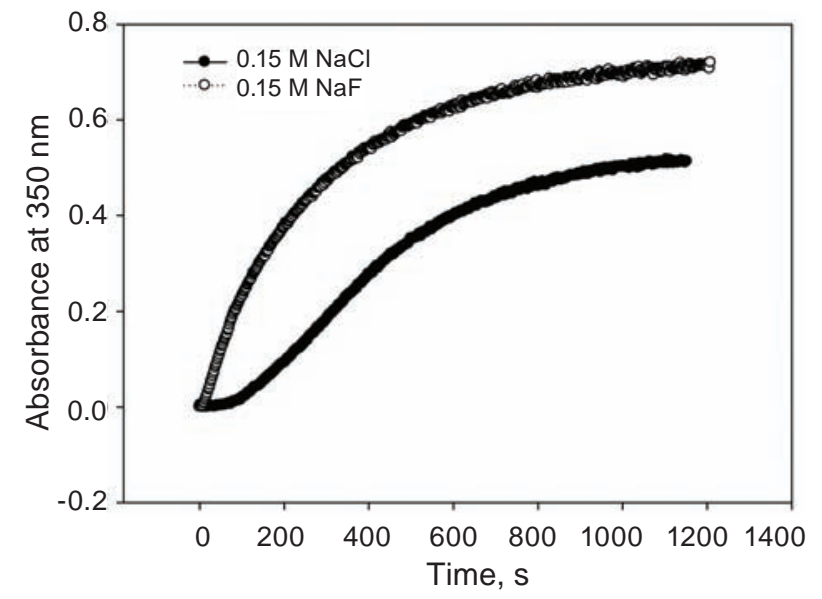

Fig. 5. Effect of chlorine anions and fuorine anions on fibrin polymerization in the monomeric fibrin system $\operatorname{des} A B(\boldsymbol{A})$ and thrombin-activated fibrinogen (B). Each curve represents the averaged curve of 4 independent experiments

anions exhibit a much greater inhibitory effect on the process of native fibrin structure refolding compared to fluorine anions (Fig. 5, A).

To determine the rate of formation of fibrin in the process of fibrinogen polymerization, activated by thrombin, we used the method of determination of fibrinogen in blood plasma, developed in the laboratory of Academician V. O. Belitzer [25]. Two points were selected on thrombin-activated fibrinogen polymerization curves (Fig. 5, B) at $384 \mathrm{~s}$ for chlorine anions and $360 \mathrm{~s}$ for fluorine anions, at which the polymerization reaction was stopped by adding to the clot ATIII to a concentration of $3 \mu \mathrm{g} /$ $\mathrm{ml}$ in a mixture with excess heparin to stop the activation of fibrinogen activation by thrombin.

At the same time, the clots were wound on glass rods, washed and dissolved in $1 \mathrm{ml}$ of $0.2 \%$ acetic acid, and their absorbance and the absorbance of the incubation medium after removal of the clot ("supernatant") at 280 and $350 \mathrm{~nm}$ were determined (Table).

Determination of the amount of fibrin formed in the fibrin clot in the reaction medium in the fibrinogen + thrombin system in the presence of $\mathrm{NaF}$ and $\mathrm{NaCl}$ respectively at 360 and $384 s(n=4)$

\begin{tabular}{l|c|c}
\hline & $\mathrm{NaF}, \mu \mathrm{g} / \mathrm{ml}$ & $\mathrm{NaCl}, \mu \mathrm{g} / \mathrm{ml}$ \\
\hline Fibrin clot & $158.0 \pm 4.7$ & $166.0 \pm 5.0$ \\
Fg in “supernatant” & $113.0 \pm 5.7$ & $113.0 \pm 8.9$ \\
Total & $271.0 \pm 11.1$ & $280.0 \pm 9.5$ \\
\hline
\end{tabular}

Based on these data, the average rate of fibrin formation in the presence of chlorine and fluorine anions was calculated, which was $0.44 \pm 0.01$ and $0.43 \pm 0.01 \mu \mathrm{g} / \mathrm{s}$, respectively $(n=4)$. These results are consistent with those obtained by DiCera [26], who showed for $\mathrm{NaF}$ and $\mathrm{NaCl}$ salts that in the concentration range from 50 to $800 \mathrm{mM}$, the rate of cleavage of fibrinopeptides A and B from fibrinogen and fibrin desA varied equally depending on the change in salt concentration.

Thus, the rate of fibrin desAB formation is equally dependent on the concentration of $\mathrm{NaF}$ or $\mathrm{NaCl}$ in the reaction medium and the enzymatic stage does not contribute to different degrees of inhibition of the rate of fibrin polymerization reaction by these salts. On the other hand, these data support the notion that in the concentration range of 0.1-0.225 M chlorine anions regulate the fibrillar structure of the clot by inhibiting the rate of fibrin polymerization, (Fig. 5) [10].

Determination of chlorine anion content in the fibrin clot formed in the Fg + thrombin system. The amount of chlorine anions bound to the fibrin in the clot was determined using a mercurimetric method of titrating a solution containing chlorine anions with a solution of divalent mercury nitric acid [18], (see Materials and Methods). The amount of fibrin clot bound chlorine anions was found to be $6.7 \pm 0.21 \mu \mathrm{g}$, which was 195 of micromoles. Taking into account that the amount of fibrin in the fibrin clot was 2.94 of micromoles, the number of chlorine atoms per 1 molecule of fibrin was 66 . 
As shown by X-ray structural studies, contact zones important for the interaction of fibrin molecules in the process of polymerization contain polypeptide loops [3, 4, 22]. X-ray analysis of the glu-plasminogen molecule revealed 4 chlorine atoms involved in maintaining its inter-domain contacts [27]. Chlorine anion atoms in glu-plasminogen interact with positively charged functional groups of the amino acid side radicals (lysine, arginine, histidine), which are part of the loops of adjacent domains. Taking into account that the number of polymerization sites and contact zones important for polymer fibrin formation is 20 per fibrin molecule, the number of chlorine anions bound to the molecule in the fibrin clot is sufficient for the specific inhibitory function. Given that the square of the fibrinogen molecule surface is $\sim 2054 \mathrm{~nm}^{2}$ and the diameter of chlorine anion is $0.36 \mathrm{~nm}$, we can assume the high selectivity of bonding of chlorine atoms to the fibrin clot.

Effect of chlorine and fluorine anions on the exposure of neoantigenic determinants (NAD) in the 119-135 region of the B $\beta$-chain of the fibrinogen molecule. It has been shown previously that cleavage of fibrinopeptide A from fibrinogen causes conformational changes in the 119-135 region of the $\beta$-chain of fibrinogen during its transformation into fibrins that are detected by the fibrin-specific mono-
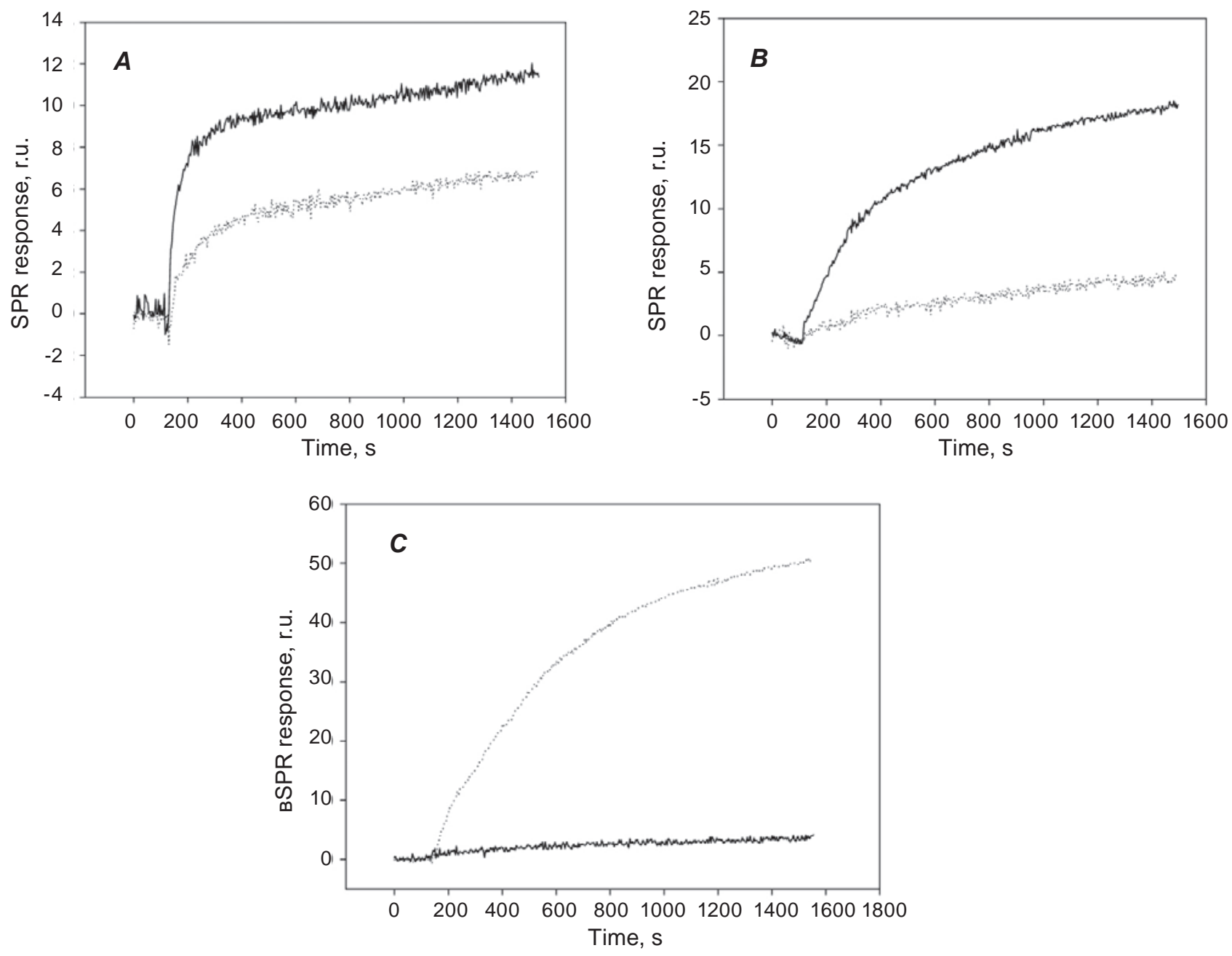

Fig. 6. SPR analysis of the binding of monomeric fibrin desAB (3 $\mu \mathrm{g} / \mathrm{ml})$ (A) and fibrin desAB (B) formed in situ in the Fg + Thr system $(3 \mu \mathrm{g} / \mathrm{ml}+0.1 \mathrm{NIH} / \mathrm{ml})$, with $\mathrm{mAT} F \mathrm{FI}-3 \mathrm{c}$, immobilized on a chip, in the presence of $1 \mathrm{mM}$ GPRP, $0.15 \mathrm{MNaF}$ or $0.15 \mathrm{M} \mathrm{NaCl}$. The graph (C) shows the binding of fibrin desAB formed in situ in the Fg + Thr system $(3 \mu \mathrm{g} / \mathrm{ml}+0.1 \mathrm{NIH} / \mathrm{ml})$ with FnI-3c mAb immobilized on a chip in the presence of $1 \mathrm{mM}$ GPRP and $0.225 \mathrm{M} \mathrm{NaF}$ or $\mathrm{NaCl}$. In all graph, the action of $\mathrm{NaCl}$ is represented by the lower curve and the action by NaF by the upper curve 
clonal antibody FnI-3c. In order to determine how the presence of chlorine and fluorine anions in the polymerization reaction medium will affect the rate of structural changes in the monomer molecule the fibrin desAB formed in situ in the Fg + thrombin system, the effect of chlorine and fluorine anions on the rate of binding of the monomeric fibrin des-AB to immobilized on the immunosensor chip of monat I-3c was analyzed by the surface plasmon resonance method, Fig. 6, $A, B, C$. To retain in situ fibrin des$\mathrm{AB}$ in the monomeric state, a GPRP peptide was added to the $\mathrm{Fg}+\mathrm{Thr}$ system to $1 \mathrm{mM}$ concentration.

Initially, we compared the binding of fibrin desAB monomer, having a NAD formed, with a mAb I-3c immobilized on an immunosensory chip in the presence of $\mathrm{NaCl}$ and $\mathrm{NaF}$ at a concentration of $0.15 \mathrm{M}$ each. It was found that $\mathrm{NaCl}$ inhibits the binding rate of fibrin desAB to $\mathrm{mAT} F \mathrm{FI}-3 \mathrm{c}$ by 2.13 times greater than $0.15 \mathrm{M} \mathrm{NaF}$ (Fig. 6, A). At the same time, the monomeric fibrin desAB formed in situ in the Fg + Thr system binds to mAT FnIc-3c in the presence of $0.15 \mathrm{NaCl} 5.1$ times slower than in the presence of $0.15 \mathrm{M} \mathrm{NaF}$ (Fig. 6, B).

Comparing the binding rate of the monomeric fibrin desAB formed in situ in the $\mathrm{Fg}+\mathrm{Thr}$ system with the $\mathrm{mAb} \mathrm{I}-3 \mathrm{c}$ in the presence of $0.225 \mathrm{M} \mathrm{NaCl}$ and $0.225 \mathrm{M} \mathrm{NaF}$, we found that it was 21.4 times lower in the presence of $0.225 \mathrm{M} \mathrm{NaCl}$ (Fig. 6, B). This magnitude of inhibition of fibrin desAB binding is 1.73 times greater than that of the rate of the lateral association of fibrin desAB, which is formed in situ under the same conditions (Fig. 3), and correlates with the increase in chlorine anion concentration. These data can be regarded as evidence of inhibition by chlorine anions of the NAD exposure in the 119135 fragment of the $B \beta$-chain of the hinge region of the monomeric fibrin desAB molecule.

If by the turbidimetric method we record the rate of formation and interaction of protofibrils in the process of fibril formation and the influence on these processes of chlorine and fluorine anions, then the SPR analysis allows us to estimate the rate of structural changes in a single fibrin molecule, which is accompanied by inhibition of the rate of NAD exposure and observed as inhibition of rate of fibrin desAB binding to monAT 1-3c in the SPR analysis. It is known that chlorine anions bind to proteins, what stabilizes their structure [20, 27]. Doolittle [3] noted in the Fg molecule the mobility of D-domains in the plane of the molecule by $15^{\circ}$ each side, and in the perpendicular plane to it - by $30^{\circ}$. In his opinion, such mobility provides the required rate of $\gamma \mathrm{C}-\gamma \mathrm{C}$ contacts of the primary sites of the lateral association [22]. Inhibition of motility in the hinge region of chlorine anion can lead to inhibition of the lateral association of protofibrils and polymerization of fibrin.

Thus, the data obtained indicate that blocking by chlorine anions of the conformational rearrangement in the process of transformation of a fibrinogen molecule into fibrin and subsequent interactions of the polymerization sites may be one of the important factors of inhibition of both the process of formation of protofibrils and their lateral association, which leads to a slowdown in the formation of polymeric fibrin and the blood clot as a whole.

Conflict of interest. Authors have completed the Unified Conflicts of Interest form at http://ukrbiochemjournal.org/wp-content/uploads/2018/12/ coi_disclosure.pdf and declare no conflict of interest.

\section{ПОРІВНЯЛЬНИЙ АНАЛІЗ ВПЛИВУ АНІОНІВ ХЛОРУ І ФТОРУ НА ПОЛІМЕРИЗАЦІЮ ФІБРИНУ}

\author{
Л. В. Пирогова ${ }^{1}$, Г. К. Березницький, \\ Г. К. Гоголінська ${ }^{1}$, Т. М. Платонова ${ }^{1}$, \\ I. М. Колеснікова ${ }^{1}$, О. О. Масенко ${ }^{1}$, \\ Р. Ю. Маруніч ${ }^{1}$, П. Ю. Цап ${ }^{1}$ Ю. В. Ушенін ${ }^{2}$, \\ С. М. Макогоненко ${ }^{1 凶 . ~ В . ~ Л у г о в с ь к о и ̆ ~}$ \\ ${ }^{1}$ Інститут біохімії ім. О. В. Палладіна \\ НАН України, Київ; \\ ${ }^{2}$ Інститут фізики напівпровідників \\ ім. В. Є. Лашкарьова НАН України, Київ; \\ 凶e-mail: ymakogonenko@gmail.com
}

Досліджено вплив солей $\mathrm{NaCl}$ i NaF в межах 0,1-0,225 М концентрацій на окремі стадії полімеризації фібрину, а саме: швидкість активації фібриногену тромбіном, швидкість формування протофібрил, швидкість латеральної асоціації протофібрил і величину максимального поглинання згустку при 350 нм. Встановлено, що аніони хлору однаково гальмують швидкість утворення фібрину із фібриногену і формування протофібрил за дії тромбіну. Показано, що аніони хлору значно ефективніше аніонів фтору інгібують швидкість латеральної асоціації і максимальне поглинання згустків із фібрину desA та desAB. Було визначено компоненту інгібувальної дії аніонів хлору, не пов'язаної з іонною 
силою розчину, і показано іiі вплив на окремі стадії полімеризації. Знайдено, що аніони хлору зв'язуються з фібриновим згустком. Із використанням методу поверхневого плазмонного резонансу і фібринспецифічного мон AT FnI-3c встановлено, що швидкість експозиції неоантигенної детермінанти монАТ в шарнірних регіонах молекули фібриногену в процесі іiї трансформації у фібрин за дії тромбіну гальмується аніонами хлору в кореляції з гальмуванням швидкості латеральної асоціації протофібрил. Висловлено припущення, що інгібувальна дія аніонів хлору складається з іонної компоненти і з компоненти, що блокує конформаційну рухливість молекули шляхом зв'язування з її шарнірними ділянками i сайтами полімеризації.

К л ю ч о в і с ло ва: фібриноген, фібрин, полімеризація, аніони хлору і фтору.

\section{References}

1. Davie EW, Fujikawa K, Kisiel W. The coagulation cascade: initiation, maintenance, and regulation. Biochemistry. 1991; 30(43): 10363-10370.

2. Furie B, Furie BC. The molecular basis of blood coagulation. Cell. 1988; 53(4): 505-518.

3. Kollman JM, Pandi L, Sawaya MR, Riley M, Doolittle RF. Crystal structure of human fibrinogen. Biochemistry. 2009; 48(18): 38773886.

4. Zhmurov A, Protopopova AD, Litvinov RI, Zhukov P, Mukhitov AR, Weisel JW, Barsegov V. Structural basis of interfacial flexibility in fibrin oligomers. Structure. 2016; 24(11): 1907-1917.

5. Köhler S, Schmid F, Settanni G. The internal dynamics of fibrinogen and its implications for coagulation and adsorption. PLoS Comput Biol. 2015; 11(9): e1004346.

6. Weisel JW, Litvinov RI. Fibrin Formation, Structure and Properties. Subcell Biochem. 2017; 82: 405-456.

7. Ferry JD. Polymerization of fibrinogen. Physiol Rev. 1954; 34(4): 753-760.

8. Belitser VA, Varetskaia TV, Tarasenko LA. Polymerization of the fibrin-monomer and its relation to the pH. Ukr Biokhim Zhurn. 1965; 37(5): 665-670. (In Ukrainian).

9. Lugovskoi EV, Belitser VA. The study of mechanism polymerization of fibrin with using of natural salts. Biochemistry. 1971; 36(1): 129137. (In Russian).
10. Di Stasio E, Nagaswami C, Weisel JW, Di Cera E. Cl- regulates the structure of the fibrin clot. Biophys J. 1998; 75(4): 1973-1979.

11. Varetskaya TV. Microheterogeneity of fibrinogen. Cryofibrinogen. Ukr Biokhim Zhurn. 1960; 32(1): 13-24. (In Ukrainian).

12. Varetskaya TV. Preparation of a fibrin monomer and studies on some of its properties. $U \mathrm{kr}$ Biokhim Zhurn. 1965; 37(2): 194-206. (In Ukrainian).

13. Lugovskoy EV, Gritsenko PG, Kolesnikova IN, Lugovskaya NE, Komisarenko SV. A neoantigenic determinant in coiled coil region of human fibrin beta-chain. Thromb Res. 2009; 123(5): 765-770.

14. Lugovskoy EV, Kolesnikova IN, Gritsenko PG, Zolotareva EN, Gaffney P, Nieuwenhuizen W, Komisarenko SV. A neoantigenic determinant in the D-dimer fragment of fibrin. Thromb Res. 2002; 107(3-4): 151-156.

15. Koide $\mathrm{T}$. Isolation and characterization of antithrombin III from human, porcine and rabbit plasma, and rat serum. J Biochem. 1979; 86(6): 1841-1850.

16. Solov'ev DA, Ugarova TP. Isolation and characteristics of alpha-specific thrombin-like enzymes from venoms of the common pit viper (Agkistrodon halys halys) and the eastern pit viper (the central Asian subspecies Agkistrodon halys blomhoffii). Biokhimiia. 1993; 58(8): 12211233. (In Russian).

17. Carr ME Jr, Hermans J. Size and density of fibrin fibers from turbidity. Macromolecules. 1978; 11(1): 46-50.

18. Alekseev VN. Quantitative analysis. M.: Chemistry, 1972. $504 \mathrm{p}$.

19. Lugovskoi EV, Makogonenko YeM, Komisarenko SV. Molecular mechanisms formation and degradation of fibrin. K.: Naukova Dumka, 2013. 230 p. (In Russian).

20. Collins KD. Charge density-dependent strength of hydration and biological structure. Biophys $J$. 1997; 72(1): 65-76.

21. Webb JL. Enzyme and metabolic inhibitors. Academic Press. New York and London. 1966. M. Mir. 254 p.

22. Yang Z, Mochalkin I, Doolittle RF. A model of fibrin formation based on crystal structures of fibrinogen and fibrin fragments complexed with synthetic peptides. Proc Natl Acad Sci USA. 2000; 97(26): 14156-14161. 
23. Tsurupa G, Pechik I, Litvinov RI, Hantgan RR, Tjandra N, Weisel JW, Medved L. On the mechanism of $\alpha \mathrm{C}$ polymer formation in fibrin. Biochemistry. 2012; 51(12): 2526-2538.

24. Tanaka Y, Nakaya S, Yoshioka Y, Yoshida Y, Hanaoka H, Kawamura R, Yasuda N. Hydration of fibrinogen, fibrin, and fibrin degradation product (FDP) as estimated by nuclear magnetic resonance (NMR) spectroscopy. Blood Coagul Fibrinolysis. 1991; 2(2): 243-249.
25. Khodorova EL. Determination of fibrinogen in small quantities of blood. Ukr Biokhim Zhurn. 1958; XXX(5):770-775. (In Ukrainian).

26. Vindigni A, Di Cera E. Release of fibrinopeptides by the slow and fast forms of thrombin. Biochemistry. 1996; 35(14): 4417-4426.

27. Xue Y, Bodin C, Olsson K. Crystal structure of the native plasminogen reveals an activationresistant compact conformation. $J$ Thromb Haemost. 2012; 10(7): 1385-1396. 